\title{
Understanding the Meaning of Self-Identity Construction of Salatiga Community
}

\section{Memahami Makna Konstruksi Identitas Diri Masyarakat Salatiga}

\author{
Rini Darmastuti ${ }^{1}$, Sri Winarso Martyas Edi ${ }^{1}$, Erwien Christianto ${ }^{1}$, \\ Titi Susilowati Prabawa ${ }^{1}$ \\ ${ }^{1}$ Study Program of Public Relations, Faculty of Information and Technology, \\ Universitas Kristen Satya Wacana, J1. Diponegoro 52-60 Salatiga, \\ Central Java 50711, Indonesia \\ *Corresponding author, e-mail: rini.darmastuti@uksw.edu
}

\begin{abstract}
The Salatiga community is unique than other communities. It lies in the identity they have. Salatiga community had always interacted with the migrants, since the Dutch colonial era. Logically, interactions with migrants will influence the identity of the Salatiga community. In fact, the identity of the Salatiga community still present to this day. Interaction with migrants actually create tolerance. Using a constructivist approach, this paper attempts to construct the identity of Salatiga community. This article using qualitative method with an ethnographic approach to communication. Based on the analysis conducted, as the first place, the construction of Salatiga community identity is the manifestation of Raden Mas Said's doctrine which emphasizes on togetherness, and accepting others. Secondly, the doctrine of Raden Mas Said become a basic for the emergence of multiculturalism understanding in the lives of the Salatiga community. Thirdly, the identity of the Salatiga community is a symbol of tolerance.
\end{abstract}

Keywords: Identity Construction, Salatiga Community, Multiculturalism, Tolerance.

\begin{abstract}
Abstrak
Masyarakat Salatiga adalah masyarakat yang unik dibandingkan masyarakat lainnya. Keunikannya terletak pada identitas diri yang mereka miliki. Masyarakat Salatiga selalu berinteraksi dengan para pendatang, sejak jaman penjajahan Belanda. Logikanya, interaksi yang dilakukan dengan pendatang akan mempengaruhi identitas diri mereka. Faktanya, identitas masyarakat Salatiga tetap bertahan sampai sekarang. Interaksi dengan pendatang justru memunculkan toleransi. Dengan menggunakan pendekatan konstruktivis, tulisan ini berusaha untuk mengkonstruksi identitas dari masyarakat Salatiga. Artikel ini menggunakan metode kualitatif dengan pendekatan etnografi komunikasi. Berdasarkan analisis yang dilakukan, hal yang pertama, konstruksi identitas masyarakat Salatiga merupakan pengejawantahan dari ajaran Raden Mas Said yang menekankan pada kebersamaan dan penerimaan orang lain. Kedua, ajaran Raden Mas Said ini menjadi dasar memunculnya pemahaman multikulturalisme dalam kehidupan masyarakat Salatiga. Ketiga, Identitas Masyarakat Salatiga yakni simbol toleransi.

Kata Kunci: Konstruksi Identitas, Masyarakat Salatiga, Multikulturalisme, Toleransi.
\end{abstract}

\section{Introduction}

Salatiga is a small city with its unique identity of the society. Previous data and historical paper society of Salatiga show their open character towards the new immigrant. The society is interacting and having relations with them, as in their era.

As in Dutch colonialism era, Salatiga community had lots of interactions with the Dutchman and European newcomers and immigrants. The location of Salatiga-600-850 meter above sea level-makes it a special place for them. They called Salatiga as the most 
beautiful place in the Middle of Java. In mid- $19^{\text {th }}$ century till early $20^{\text {th }}$ century, Salatiga was known as a resort for the government official of both Dutch and Europe (Dhave, 2012).

Newcomers of Dutch and Europe brought big impacts towards the social life of Salatiga. The society was intentionally conditioned to interact and to have relation with Dutchman and European newcomers. These impacts were increasing when 'Burgemeester' (Major of City) helped by 'Gemeenteraad' (Council of City) worked hard to carry out various developments in Salatiga while introducing public facilities such as paved roads, electricity, 'leideng' water and sidewalks. Even though these projects were originally intended to ease the white people, it cannot be denied that indigenous people also felt the benefits both directly and indirectly (Supangkat, 2010).

These projects of constructions made the society grew far more advanced than other regions. Indirectly, Salatiga also felt the postive impact of the progresses and amenities. This led to a well-established relationship between the people of Salatiga and the Dutchman and European society. Knowledge transfer and cultural transfer eventually occur in this interaction. (Berger \& Luckmann, 1990) claims that humans whom go into the process of 'being' are not only reciprocal with a particular natural environment, but also with a specific cultural and social order that is linked through the influence of significant others who took care of him. In other words, from the moment of birth, human development continues to experience socially determined interference. According to (Books, Peter, \& Berger, 1967), society has a very important role in the life of every human being at this level. Society is a dialectical phenomenon as a result of human products built on the basis of human consciousness. 'Society is a dialectic phenomenon in that it is a human product, and nothing but a human product, that yet continuously acts back upon its producer. Society is a product of man it has no other being except that which is bestowed upon it by human activity and consciousness. Society was there before the individual was born and it will be there after he has died. The two statement, that society is the product of man and that man is the product of society, are non contradictory.'

As Berger, there is a reciprocal relationship between people and humans. Society is a human product; human is a product of society. There is a dependency between one and another. The existence of people's lives is determined by the existence of other human beings, in order; direction and stability. The presence of Dutchman and Europeans society built a condition of dependence on existing facilities for Salatiga community, as the Dutchman and European society had mutually. They had a great dependency with the Salatiga society. As a result, there was a reciprocal relationship between the people of Salatiga and the newcomers of Netherlands and Europe.

Reciprocal relations between the Salatiga community and the newcomers also occurred during the Javanese empire. The interaction occurred when the royal envoys of Mataram Kingdom and king had a journey from Solo to Semarang, and vice versa. Located in the middle of Solo, Semarang, and Yogyakarta, Salatiga was an option for them as a place of rest along the journey. Salatiga was considered as a safe city. It was safe from both the influence of Dutch and robbers. Therefore, Salatiga was considered as the place where several important histories were held, including an important conference; Salatiga Agreement.

Universitas Kristen Satya Wacana is a public place where society and immigrants interact. It is a 'meeting spot'-- as it is in the midst of the city of Salatiga -- for the indigenous people and new comers having communication. As a university which is famous for 'Indonesia mini', Universitas Kristen Satya Wacana receives around 4,000 
ethnic students annually. Thousands of students who came to Salatiga brought their own habitude and culture.

In logic, there were two possibilities associated to cultural acculturation. The first was that the society will be influenced by the foreign culture and habits brought by immigrants, thus would probably change, even replaced the identity of the Salatiga. The second was that the foreign culture and habits of the immigrants will be eroded, as they were 'forced' to adapt and to accept the indigenous culture and habits of the society.

Uniquely, those two things above did not happen in Salatiga. The society continued to live in their culture and habits, while the immigrants who come from various tribes, habitudes and cultures live according to their culture. Interestingly, in Salatiga, newcomers and immigrants actually have the freedom to interact with their ethnic communities, even keep living in their culture. This can be seen from the activities held by one of an ethnic community in Salatiga through cultural expo, as well as culinary tourism. This tourism serves traditional foods from every ethnicity in Indonesia. This uniqueness is one of the characteristics of the Salatiga community identity. The identity of the Salatiga community is a manifestation of the cultural diversity of the Indonesian. The diversity of Indonesian culture is reflected in the part of local cultures that develop in the community. The diversity is formed not only internally, but also because of external influences that form a culture in a region (Febriana, Setiawan, \& Ersyad, 2019).

This paper discusses about the identity construction of the Salatiga community. In the midst of the influence of new comers (from the Dutch colonial era, the Javanese empire, and to this day) the society of Salatiga still has a self-identity. On the other hand, new comers also have the freedom to remain 'themselves'. This condition is very different from the identity of newcomers in several cities, for example in Yogyakarta or in Bali. The dominance of Yogyakarta culture or Balinese culture is very strong, making every new comer who comes to these cities finally dissolve in the culture of Yogya or Bali. As a result, the identity of the entrants will slowly erode.

(Madibbo, 2012) in his research entitled 'Conflict and the Conceptions of identities in the Sudan', examined the Sudanese identity in the middle of ongoing conflict. The very liquid boundary between Africanism and Arabism in this country has an impact on the emergence of many identities in the lives of Sudanese society as a result of globalization, migration and social ties among groups. The research conducted by Amal Ibrahim is very different from the conditions in Salatiga. Logically, the existence of connections and networks among the Salatiga society and the Dutch colonial government, European society, royal envoys and the immigrant students, should have created many identities in the lives of the Salatiga people. In fact, in this diversity and pluralism, people's identity remains unchanged.

The fact above is the main background for constructing the identity of the Salatiga community. The aim of this paper is to contribute in enriching the literature of identity construction. It is moreover to reduce a gap that arises between empirical evidence about the identity of the Salatiga community and the theory of identity from previous studies, such as research conducted by (Lawler, 2005) In his research entitled 'Introduction: Class, Culture and Identity', Lawler saw that class complexity is not just a job or economic category. Classes are considered as one axis where identity and culture are formed. In Lawler's view, class has a very large role to determine identity and culture. The identity construction carried out by Lawler is very different from the construction of the Salatiga community. The differences in class among the Dutch colonial government, European society, and the royal envoys who had a higher class would eliminate the 
identity of the Salatiga community. In fact, the identity of the Salatiga community continues to this day, although it was influenced by immigrant students from various ethnic groups in Indonesia. In the current differences and plurality, it will logically lead to conflict. Uniquely, plurality and differences in Salatiga actually create tolerance. This is proven by the pinned predicate for the city of Salatiga as the second tolerant city in 2017.

Based on the background above, the focus of this paper is how is the construction of the identity of the Salatiga community, and what symbols and messages do they want to convey through the construction of the identity of the Salatiga community. This paper is different from previous articles and studies as the renewal and originality to review the identity construction of the Salatiga community within the interaction with immigrant communities from the perspective of intercultural communication. In addition, this paper tries to understand the meaning of the identity of the Salatiga community based on the messages and symbols that are raised when they communicate with immigrant communities who have different cultural backgrounds.

\section{Methodology}

This paper is based on the results of research conducted in 2017-2018 titled 'Media Literacy Model for Children of Elementary School by using Interactive Multimedia in the Concept of Local Wisdom of the Salatiga people'. The research was funded by Ristekdikti and the application of product research scheme was conducted in Salatiga of 2017-2018. One of the objectives of this research is to explore the local wisdom of the Salatiga community. Salatiga's local wisdom generated from this research is used as data and groundwork to describe the identity, and to express the meaning of messages and symbols of the identity of the Salatiga community.

The paradigm used in this study is the social constructivist paradigm. Creswell (2013) said that individuals in social constructivist paradigm always try to understand the world they live and work. These individuals then develop subjective meanings of the experiences they get. The meaning refers to an object or something (Creswell, 2013). Main problems raised in this study are the identity construction of the Salatiga community in the middle of social change and cultural acculturation with immigrant communities. Therefore, this research used descriptive qualitative using ethnographic research methods of communication. It emphasized the identity construction of the Salatiga community and the cultural meaning of the Salatiga community as a communicative situation, communicative events and communicative actions.

There are several ways that can be used to collect data in ethnographic research on communication. (Brewer, 2000) said that data collection methods used in this study were in-depth interviews, active role-observations, and documentary analysis. Data were obtained through direct observation and in-depth interviews. Observations were carried out in the center of Salatiga to explore the cultural richness and local wisdom of the Salatiga people. In-depth interviews were conducted towards cultural, teacher and community leaders in Salatiga, as the key people in this study. After conducting in-depth observations and interviews, the researcher constructs the messages obtained from the speakers.

\section{Results and Discussion}

Identity is an inherent label and is always carried by people both as individuals and as part of the social community. It is through this identity that the existence of an 
individual will be known, both as an individual who stands alone and as a member of a group. For the Salatiga community, identity is a label attached to themselves as individuals and as part of a group. Identity is a characteristic of the 'uniqueness' that they have and which distinguishes 'self' with other human beings. The identity of the Salatiga community is to connect between each individual and the community outside Salatiga, through the communication they make. The identity of Salatiga community cannot be separated from the relations between Salatiga community and themselves, and Salatiga community with others. There is a relationship between self-narration and narrations of others in the process of forming the identity of the Salatiga community. This is as stated by Michael Hecht and his colleagues in the theory of identity communication, which says that identity is the main link between individuals and society and communication is the link so that this relationship occurs (Littlejohn \& Foss, 2009) .

Collier and Milt Thomas (Malik, 2018) further formulated seven basic traits of cultural identity. First, individuals have various cultural identities that may arise in behavior, including citizenship, race, ethnic, social class, gender, political choice, religion, and others. Cultural identity exists when the behavior patterns of all individuals show the identity of their membership in group or groups. Second, from individual perspective, these diverse cultural identities differ according to the situation and also vary over time and intagection. Third, cultural identity varies within certain scope, referring to how widely 'held' and genagelized they are. Fourth, cultural identity is formed through the process of recognition (self concept) and assumption (view by others). Fifth, the intensity at which particular identity is recognized and perceived differently depends on the situation, context, topic, and relationship that exists. Sixth, cultural identity survives through time and space, and changes significantly. Seventh, cultural identity has two aspects both content and relational.

Castells (Samovar, Porter, McDaniel, \& Roy, 2014) said that identity is an integral part of our lives. Identity plays a central role in all of our activities that functions as a source of self-definition. In other words, we are the ones who govern the meaning around our lives. In this part, when someone comes from many identities, these origins will give effect and become a foundation for him when he gives meaning to the world around him. Identity is not a simple thing, which is only about identity. Identity is a very complex problem because behind it there is a very deep meaning. Identity is a source of meaning (Castells, 2011).

When referring to Castells' opinion, logically the Salatiga community's identity should also be influenced by the Dutch, European, Hindu cultures during Mataram kingdom, as well as the cultures brought by students from all over the country. Interestingly, in the midst of the influence of Dutch, European cultures and cultural influences brought by immigrant students, the Salatiga community still have their own identity of Salatiga people. Therefore, when we construct the identity of the Salatiga community, we are actually asking about how the Salatiga community see themselves and how the community see themselves. This is as Barker said, that understanding the problem of identity means understanding how we see ourselves and how others see us (Barker, 2011). Hecht said that our identity is a 'code' that defines our membership in diverse societies. This code consists of symbols of clothing and ownership, words such as self descriptions or objects that we usually say, and meanings that we associate with these objects (Littlejohn \& Foss, 2009).

Related to Hecht and Barker's opinion, the understanding of Salatiga community about who they are and how others see themselves can be traced from 'code' through the 
symbols they use in everyday life, as well as from the history of this city. The naming of the city of Salatiga was inseparable from the role of 'Ki Ageng Pandanaran II' who at that time served as the Regent of Semarang. Based on the story at that time, after ' $\mathrm{Ki}$ Ageng Pandanaran II' resigned from his position and exiled to the south, when he arrived at the Perdikan area, 'Ki Pandanaran II' and his family were robbed by 3 people. These three robbers were finally defeated and became his followers. The city of Salatiga itself emerged from the word Salatiga which was said when they asked for help when robbed, "Kangmas, tulung! Wontent yang, salah telu!" (Sir please help! There are three robbers). In addition to this version, there is another version related to the name of Salatiga. Salatiga comes from the words 'sela' or 'selo' (stone) and 'tigo' (three). The three stones came from a temple which according to a legend was located next to the river of Kali Taman, Benoyo (Dhave, 2012).

Understanding of self, formed through two relations processes, called relations with others and themselves. Relation with other people occur when Salatiga community built relations with Dutch and European societies during the Dutch colonial period, with emissaries from the Javanese empire as well as with immigrant students today. Referring to Berger's opinion, the relationship in the process of forming self-identity occurs in several stages, namely the externalization stage, the objectivities stage and the internalization stage. For the Salatiga community, the externalization stage (selfadjustment) occurs when they both physically and mentally carry out activities as a result of their cultural production. During the Dutch colonial period, the form of Salatiga cultural production was strongly influenced by Dutch culture and European culture. We can see this from several buildings in Salatiga, which were built during the Dutch colonial era and they are still used today. One of them is the house of the Regent of Baron van der Schoot-of Heeckeren, which is well known as the 'flat building' or the 'Papak' building because the roof is flat.

During the Javanese kingdom, the externalization stage (adaptation) was influenced by Hindu culture. Jarwadi as the head of Tourism and Culture at the Salatiga Office in an interview conducted on July 21, 2017 explained that the culture of the Salatiga community was based on Hindu culture. This opinion is based on several writings obtained in the Plumpungan Inscription. Based on this Inscription, since 750 AD Salatiga is the 'Perdikan' region. 'Perdikan' means an area within a particular kingdom exempt from all obligations to pay taxes or tributes because it has certain specificities (Pemerintah Kota Salatiga, 2017).

According to Amrih (another source), another figure who had a major influence in the process of externalizing of Salatiga community was 'Raden Mas Said' or better known as 'Pangeran Samber Nyowo' (Prince Samber Nyowo) or Mangkunegoro. In an in-depth interview conducted on July 20, 2017, he explained that the influence of 'Pangeran Samber Nyowo' was very strong in the culture of Salatiga. Pangeran Samber Nyowo had his fighting tagline 'TIJI-TIBEH' (one dies, all die), or the opposite 'Mukti Siji Mukti Kabeh' (one is happy then all will be happy). This slogan contains a local wisdom that is togetherness - when one is prosperous, then all will be prosperous (Mangadeg, 1988). The philosophies of independence, freedom and togetherness are the teachings taught by 'Raden Mas Said'.

The identity of Salatiga community is largely determined by the attitude of the Salatiga community when they give meaning toward everything around them. Calhoun (Castells, 2011) states that the process of constructing cultural attributes is given priority over other sources of meaning. For the people of Salatiga, the construction of the meaning 
of all parts of their lives cannot be separated from the culture they have and they live. In the social interaction, the cultural identity is always inherent in them, both in the way of acting or reacting, and symbolized through the clothes and accessories worn. This condition can not be separated from the existence of indigenous institutions that have central role in upholding indigenous rules. An indigenous community can maintain and preserve their cultural identity, when customary institutions have a central role in enforcing customary rules. Therefore that all community members have strong ties to their cultural identity (Malik, 2018) .

According to Jarwadi as one of the keypersons in this study, the culture of the Salatiga community is strongly influenced by the culture of Solo and Yogyakarta as an application of the teachings of 'Raden Mas Said'. As a result, the identity of the Salatiga community is strongly influenced by the cultural identities of Solo and Yogyakarta, and is based on the teachings of 'Raden Mas Said' about living through mutual respect; with the principle thatone is happy all will be happy. This is as said by 'Murathan Mungan', "Identity is a concept of our age that should be used very carefully. All types of identities, ethnic, national, religious, sexual or whatever else can become your prison after a while. The identity that you stand up for can enslave you and close you to the rest of the world" (McDaniel, Samovar, \& Porter, 2012).

Mapping the culture of Salatiga community and the local wisdom of Salatiga community, is the first step that must be taken to construct the identity of the Salatiga community because the identity of the Salatiga community cannot be separated from the culture and local wisdom owned by the community.

For newcomers, Salatiga is a nice small town. In addition to its geographical location, the friendly and respectful attitude of Salatiga people are other factors that make migrants very fond of living in Salatiga. In the Focus Group Discussion conducted by the author on July 17, 2018, several discussion participants said that Salatiga community is a very friendly and caring community. This is as said by Diana, a student from Rote said, "The Salatiga people is friendly. They like to help". Rudi, a student from Papua also said, "The Salatiga people really care of each other. Every time I walk, I am always greeted".

For Salatiga people, the cultural influences of Solo and Yogyakarta and the teachings taught by 'Raden Mas Said' become the basis for everyday life. This teaching is then applied when they build relationships with other individuals. (Joseph, 1993) provides three assumptions about identity with culture. First, culture is the expression at the level of world views, ideas and practices of organically linked communities. Second, the specific identity of a community is to be understood in terms of its culture. According to this view, the members of the community not only accept membership of the community as their primary identity but also be possible to predict their behavior patterns and characteristics in the terms of community values. Third, the culture of each community is so unique that it can be fully understood only by natives. Outsiders should try to adopt the native's point of view to understand culture and rationality.

In the cultural diversity of migrants, the Salatiga community still shows its identity through an inherent identity -- identity as a friendly society, caring for others by emphasizing togetherness, mutual respect and tolerance. It is alike to the research conducted by Sinta Paramita and Mita Carrisa that 'inter-ethnic conflicts can arise due to the absence of opened mind in facing the differences, the lack of mutual tolerance and mutual respect among ethnic groups' (Paramita, Carissa, \& Tarumanagara, 2018). Referring to this research, tolerance is the basis for the creation of a society that lives peacefully. 
The application of the life principle of the Salatiga community is clearly seen in everyday life in the attitude of respecting the culture of the migrant communities. There is no domination of culture and identity of the Salatiga community towards migrant communities. In everyday life, migrants can still apply the culture that they have, gather with their ethnic communities and develop their cultures. Culinary tourism that develops in Salatiga is one proof of it. In Salatiga, we can easily find a variety of special dishes from various ethnic groups in Indonesia. At this level, the diversity of various tribes gathered in Salatiga, no longer as a form of plurality, but rather as multicultural. Conceptually, multiculturalism is different from pluralism. Pluralism isonly an acknowledgment of diversity, pluralism or diversity, that there are various kinds of races, tribes, religions or cultural groups. In contrast to pluralism, multiculturalism is more than an acknowledgment but it opens a space for access and expression for all elements of the resilience by relying on each other's identity, and then communicating with each other without having to kill each other (Nugroho \& Suryo, 2013).

Multiculturalism recognizes various potentials and legitimacy of socio-cultural diversity and differences of each ethnic group, race, religion, and cultural entity. In this view, individuals and groups from various social entities can join in society; engage in societal cohesion without losing their cultural identity, while still obtain their rights to participate fully in various fields of community activities.

From the identity construction of the Salatiga community, we can see that it is not only a society that adheres to pluralism. The Salatiga community is a society in multiculturalism that lives and interacts with various ethnicities and tribes coming from all over Indonesia. In interaction and relation with these newcomers, the Salatiga people still have their own identity, without losing the identity of the newcomers. Migrants can live in Salatiga without losing their own cultural identity. Evidence that identity of Salatiga community exists can be seen from the annual event held by the Salatiga government in collaboration with Universitas Kristen Satya Wacana which annually hold a cultural carnival. At this carnival, every ethnic living in Salatiga can display the cultural works that they have. Tolerance and mutual cooperation derived from the teachings of 'Pangeran Samber Nyowo (Mangkunegoro)' has become the basis of a culture growing in Salatiga. The attitude of tolerance held by the Salatiga community is clearly applied from the mutual respect and mutual assistance carried out by the Salatiga community at every commemoration of religious holidays. We take for example, on every 25 December, at the Christmas celebrations, Christians in Salatiga always celebrate Christmas together. This joint Christmas celebration is usually held at the Pancasila town square. When Christians are worshiping, Muslims help to guard the motorbikes and cars and help them regulating traffics and maintaining the location of worship place. Likewise, on every Idul Fitri holiday, Muslims in Salatiga hold Eid prayers together in the Pancasila town square, and Christians guard this event. Ethnic identity is a psychological foundation for someone to grow and stand. No one can take it. (Roosens, 1989) see cultural identity as a psychosocial driving force of each individual and reinforces collective ethnic groups. 


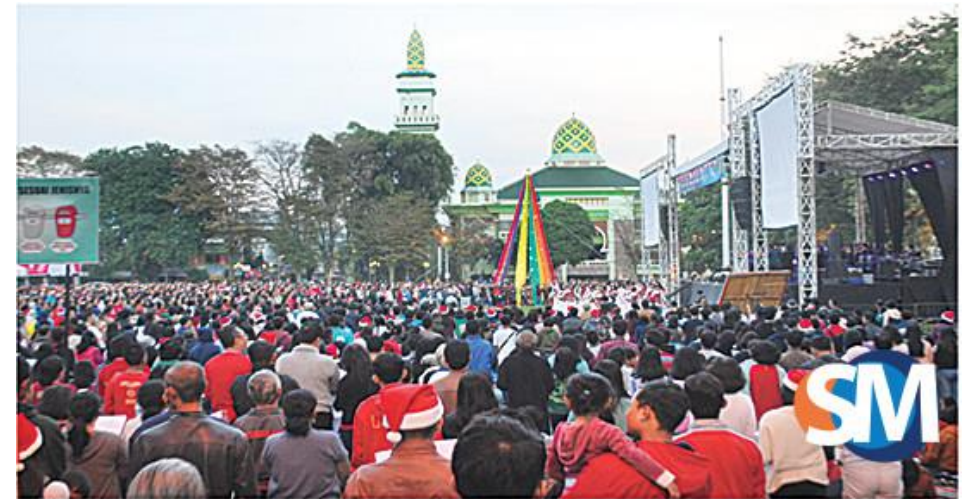

Picture 1. Christmas Celebration in Pancasila field Salatiga, as a Tolerance Action of Salatiga Community (Yuli, 2018)

This tolerance is also shown through the awardgained by the Salatiga government. The attitudes and actions of the Salatiga people who have very high tolerance, finally received an award from the central government. In 2017, the city of Salatiga was finally awarded as the second tolerant city in Indonesia.

The form of tolerance and togetherness of the Salatiga community is also applied in the form of material culture (Philipsen, 1992) said that culture is closely related to symbols and meanings used when we communicate. In other words, when we talk about culture, we cannot escape communication. This as stated by Edward T. Hall (Mulyana, 2008) between culture and communication can be likened to two pieces of currency that cannot be separated. There will be no culture without communication. Vice versa, there will be no communication without culture. Non-only culture influences communication but also is acted through and is influenced by communication (Philipsen, 1992). On the other hand, culture will shape and influence self-identity and self-awareness (Samovar, Porter, Mcdaniel, \& Roy, 2014). Charles H. Cooley (Mulyana, 2008) calls the concept of self as the looking glass-self. This concept significantly determines what others think about themselves and emphasizes the importance of people's responses which are interpreted subjectively as a primary source of self. Through the concept of 'the looking glass-self', Charles Horton Cooley gives an idea of self-concept by imagining an individual as someone else in the mind of the individual. As if a mirror was placed in front of an individual (Rakhmat, 2005).

One of the material cultures is 'Saparan'. 'Saparan' has been developed in several regions in Salatiga. According to Jarwadi, 'Saparan' was firstly developed in the Randu Acir area. In this area, the Saparan culture was developed by a very famous figure $-\mathrm{Ki}$ Hajar Sampurno. The 'Saparan' at Randu Acir is carried out every 'Sapar' month by holding a 'Wayang Kulit' performance (shadow puppet show). Local wisdom from the culture of 'Saparan' which is conducted by the Randu Acir community is mutual cooperation, mutual respect, obedience to the ancestors and obedience to parents. Referring to the opinion of George Herbert Mead, 'Saparan' is a symbol produced by humans as a form of interaction between humans and humans, and humans with nature. George Herbert Mead in his symbolic theory says that in social interactions there is a dialectic of the relationship between humans and humans and humans and nature. In Mead's view, an individual is not a slave who serves the community, but an individual who is sensitive and active. Their presence in the middle of their social environment greatly influences the environment in which they live effectively (both individually and socially) as the environment affects them. In other words, individuals have a very big role in shaping society as people form these individuals (Soeprapto, 2002). 
'Saparan' is also carried out in Tegalrejo area. 'Saparan' that carried out in this area is different from Randu Acir area. The people in Tegalrejo area clean the village, mosques and the surrounding area. According to Jarwadi, when performing 'Saparan', the people in Tegalrejo hold a 'Tayub' show. The local wisdom from the 'Saparan' carried out by the Tegalrejo community is mutual cooperation then the mutual cooperation forms togetherness and mutual understanding.

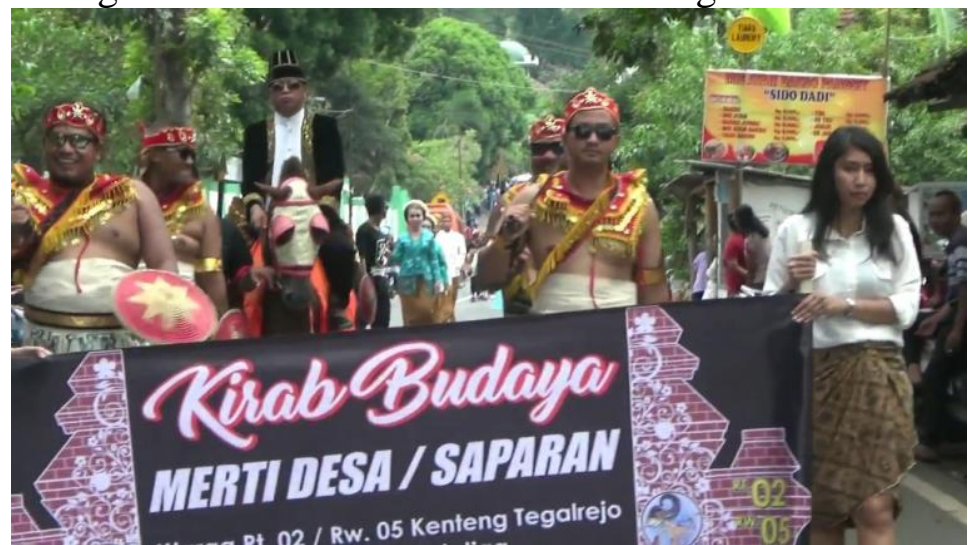

Picture 2. Culture 'Saparan' Carnival in Salatiga (source: Budaya Nusantara, 2017)

Besides 'Saparan', other cultures that have been developed in Salatiga are in the form of arts. The art emerging from the historical development of Salatiga is 'Jurit Ampil'. It is a dance featuring female dancers. The second is 'Drum Black'. This art is almost similar to a drum band but it is played by a group of people using unused household appliances as musical instruments such as pans, cormorants, and other unused appliances. The third is 'Teklek' Dance. 'Teklek' Dance is a dance performed by several people using 'teklek' (long wooden shoes that are used together at once by three or four people). The fourth is 'Ndeng Thek' and 'Topeng Ireng'. Both of these arts form a dance that develops in the Tegalrejo area and refers to the culture in Magelang. Togetherness and harmonization are the foundation used in carrying out these games. This togetherness and harmonization are forms of local wisdom owned by the Salatiga community based on tolerance between one community and another.

\section{Conclusion}

Since the ancient times, Salatiga community has been used to the migrant communities. The presence of newcomers is fully realized or in other words it has no influence on the identity of the Salatiga community. The construction building of Salatiga community identity is not an easy effort. Identity is not just self-identity, but is a label that is attached to each individual as a person or as a group member which is strongly influenced by the culture that they have.

George Herbert Mead in his symbolic theory said that an individual is not a slave who serves the community, but a person who is sensitive and active. Their presence in the middle of their social environment greatly influences the environment in which they live effectively (both will be carried out in the context of their respective cultures. (individually and socially) as the environment affects them. Interactions between one individual and another (Philipsen, 1992) said that culture is closely related to symbols and meanings used when we communicate. In other words, when we talk about culture, we cannot escape communication. This is as said by Edward T Hall (Mulyana, 2008) between culture and communication can be represented by two pieces of coin that can not be separated. There will be no culture without communication. Vice versa, there will be 
no communication without culture. 'Culture not only influence communication but also is enacted through and so is influenced by communication' (Martin \& Nakayama, 2010). On the other hand, culture will form and influence self-identity and self-awareness (McDaniel et al., 2012). Charles H Cooley (in Mulyana, 2008) calls the concept of self as the looking glass-self. This concept significantly determines what others think about themselves and emphasizes the importance of people's responses which are interpreted subjectively as a primary source of self. Through the concept of 'the looking glass-self', Charles Horton Cooley gives an idea of self-concept by imagining an individual as someone else in the mind of the individual, as if a mirror was placed in front of an individual.

From the results of the analysis in this paper, the construction of the Salatiga community identity is strongly influenced by the teachings of Raden Mas Said that emphasize togetherness, mutual respect and tolerance. There are three findings of this paper; first, the Salatiga community is a society that respects others by always focusing on togetherness, mutual respect and tolerance. Second, the Salatiga community is a society that is multiculturalism in nature, not just pluralism. Third, tolerance is a symbol of the identity of the Salatiga community.

\section{Acknowledgements}

The authors would like thank to The Ministry of Research, Technology and Higher Education of the Republic of Indonesia (Kemenristekdikti), for funds provided through the STRANAS Grant in 2018.

\section{References}

Barker, C. (2011). Cultural Studies: Teori dan Praktik, edisi terjemahan oleh Nurhadi. Yogyakarta: Jalasutra.

Berger, P. L., \& Luckmann, T. (1990). Tafsir Sosial atas Kenyataan: Risalah tentang Sosiologi Pengetahuan, terj. Hasan Basari. Jakarta: LP3ES.

Books, O., Peter, B. Y., \& Berger, P. L. (1967). Elements of a Sociological Theory of Religion. New York: Anchor Books.

Brewer, J. (2000). Ethnography. In S. Becker, A. Bryman, \& H. Ferguson (Eds.), Understanding Research for Social Policy and Social Work. Berkshire: McGrawHill Education.

Budaya Nusantara. (2017). Kirab Budaya Merti Desa Kenteng Salatiga - 05 Nopember 2017 \#1. Retrieved July 21, 2019, from 22 December 2017 website: www.youtube.com/watch?v=4p9_waET_6c

Castells, M. (2011). The power of identity (Vol. 14). John Wiley \& Sons.

Creswell, J. W. (2013). Research Design: Pendekatan Kualitatif, Kuantitatif, dan Mix (3rd ed.). Yogyakarta: Pustaka Pelajar.

Dhave, D. (2012). Salatiga, Nostalgia Masa Lalu Bersama Bangunan Tua.

Febriana, K. A., Setiawan, Y. B., \& Ersyad, F. A. (2019). Warak Ngendhog Commodification as a Kind of Creative Industry in Semarang City. Jurnal The Messenger, 11(1), 27. https://doi.org/10.26623/themessenger.v11i1.925

Joseph, S. (1993). Identity, Culture and Community. Economic and Political Weekly, 807-809.

Lawler, S. (2005). Introduction: Class, culture and identity. Sage Publications London, Thousand Oaks, New Delhi.

Littlejohn, S. W., \& Foss, K. A. (2009). Teori Komunikasi. Jakarta: Salemba Humanika. 
Madibbo, A. I. (2012). Conflict and the conceptions of identities in the Sudan. Current Sociology, 60(3), 302-319.

Malik, A. (2018). Cultural Identity and Social Interaction of Indigenous Peoples in the Middle of Modernization (Case Study of Indigenous Peoples of Kasepuhan Banten $\begin{array}{lllll}\text { Kidul). Jurnal The } & \text { Messenger, }\end{array}$ https://doi.org/10.26623/themessenger.v10i1.649

Mangadeg, Y. (1988). Pangeran Sambernyawa, Ringkasan Sejarah Perjuangannya. Surakarta: Yayasan Mangadeg.

Martin, J., \& Nakayama, T. (2010). Intercultural Communication In Contexts (5th ed.). New York: McGraw-Hill.

McDaniel, E. R., Samovar, L. A., \& Porter, R. E. (2012). Intercultural communication: A reader. Wadsworth.

Mulyana, D. (2008). Ilmu Komunikasi: Suatu Pengantar. Bandung: PT. Remaja Rosdakarya.

Nugroho, H., \& Suryo, D. (2013). Konstruksi identitas kepapuaan dalam dinamika arus demokrasi.

Paramita, S., Carissa, R. M., \& Tarumanagara, U. (2018). Inter-Ethnic Communication Barriers in Pontianak City Hambatan Komunikasi antar Etnis di Kota Pontianak. Jurnal The Messenger, 10(1), 54-62. https://doi.org/10.26623/themessenger.v10i1.550

Pemerintah Kota Salatiga. (2017). Sejarah Kota. Retrieved August 25, 2017, from 1 January 2017 website: http://www.salatigakota.go.id/TentangSejarah.php

Philipsen, G. (1992). Speaking culturally: Explorations in social communication. SUNY Press.

Rakhmat, J. (2005). Psikologi Komunikasi edisi revisi. Bandung: Remaja Rosdakarya.

Roosens, E. E. (1989). Creating ethnicity: The process of ethnogenesis. Frontiers of Anthropology, 5. Retrieved from https://psycnet.apa.org/record/1989-98740-000

Samovar, L. A., Porter, R. E., Mcdaniel, E. R., \& Roy, C. S. (2014). Communication Between Cultures (8th ed.). Boston: Wadsworth, Cengage Learning.

Samovar, L. A., Porter, R. E., McDaniel, E. R., \& Roy, C. S. (2014). Intercultural communication: A reader. Cengage Learning.

Soeprapto, R. (2002). Interaksionisme Simbolik Perspektif Sosiologi Modern. Yogyakarta: Averroes Press dan Pustaka Pelajar.

Supangkat, E. (2010). Galeria Salatiga. Griya Media.

Yuli, S. (2018, December 8). Salatiga Kota Paling Toleran Kedua. 08 December 2018. Retrieved from https://www.suaramerdeka.com/index.php/smcetak/baca/151430/salatiga-kotapaling-toleran-kedua 